\title{
ФИЗИОЛОГИЧЕСКАЯ РЕАКЦИЯ МИКРОРЕОЛОГИЧЕСКИХ СВОЙСТВ ЭРИТРОЦИТОВ КРЫС НА СТАРЕНИЕ ОРГАНИЗМА
}

\begin{abstract}
PHYSIOLOGICAL REACTION
OF MICRO-RHEOLOGICAL PROPERTIES

OF RAT ERYTHROCYTES ON AGING

OF THE ORGANISM

M. Grishan

T. Kotova

Summary. The study included 96 healthy outbred male rats, including 34 animals aged 18 months, 30 animals aged 24 months. and 32 heads at the age of 30 months. The control group consisted of 31 healthy outbred male rats at six months of age. In aging rats, an increase in the activity level of free radical oxidation processes in plasma lipids and red blood cells was found. With an increase in the chronological age in the blood of the observed rats, a decrease in the level of red blood cells-discocytes was noted, which was most pronounced in rats at 30 months of age. This was accompanied by an increase in their level of changed reversibly and irreversibly erythrocyte forms and an increase in spontaneous aggregation of red blood cells.
\end{abstract}

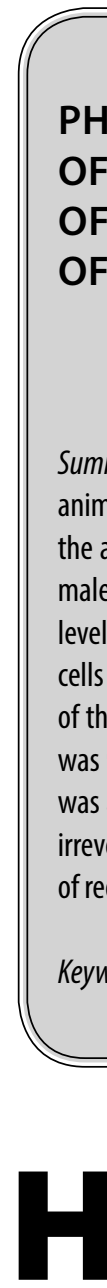

Keywords: rats, aging, red blood cells, cytoarchitecture, aggregation.

\author{
Гришан Маргарита Алексеевна \\ К.м.н., ФГБОУ ВО «Российский государственный \\ социальный университет» \\ grishanma@rgsu.net \\ Котова Татьяна Владимировна \\ К.м.н., ФГБОУ ВО «Российский государственный \\ социальный университет» \\ kotova-nm@mail.ru
}

Аннотация. В исследование взяты 96 здоровых беспородных крыс-самцов, в т.ч. 34 животных в возрасте 18 мес., 30 голов, находящихся в возрасте 24 мес. и 32 головы в возрасте 30 мес. Группа контроля состояла из 31 здоровой беспородной крысы-самца в шестимесячном возрасте. У стареющих крыс было найдено увеличение уровня активности процессов свободнорадикального окисления в липидах плазмы и эритроцитов. При повышении хронологического возраста в крови наблюдаемых крыс отмечено уменьшение уровня эритроцитов-дискоцитов, что было максимально выражено у крыс в 30 месячном возрасте. Это сопровождалось ростом у них уровня измененных обратимо и необратимо эритроцитарных форм и повышением спонтанной агрегации эритроцитов.

Ключевые слова: крысы, старение, эритроциты, цитоархитектоника, агрегация.

ме [8, с. 22]. Известно, что их реологические параметры способны изменяться на фоне физиологических и патологических процессов [9, с. 134]. Ясно, что весьма часто в старших возрастах, эти показатели могут меняться в нефизиологически выгодных границах, что, видимо, способно негативно влиять на ход микроциркуляции в органах, порой значимо усугубляя течение патологии [1, с. 563].

При этом в процессе поиска терапевтических подходов при различных патологических явлениях у человека $[4$, с. 10] сложно обойтись без изучения биологических процессов в экспериментальных моделях, осуществляющих в основном на лабораторных животных и в первую очередь на крысах. Ввиду важности эритроцитарных реологических параметров в развитии многих дисфункций, в т.ч. возрастных изменений в крови требуется разработка вариантов по их преодолению. В этой связи весьма актуально изучение аспектов агрегации и цитоархитектоники эритроцитов у стареющих крыс. Эти сведения могут послужить базой для дальнейшего поиска в экспериментальных подходах по оптимизации рео- 
логических характеристик эритроцитов в старших возрастах и дальнейшим весьма осторожным учетом этих сведений в геронтологических наблюдениях на людях $[1$, с. $616 ; 5$, с. 622$]$.

Учитывая эти обстоятельства, в работе поставлена цель - выяснить возрастные изменения микрореологических характеристик эритроцитов у крыс на поздних этапах онтогенеза.

\section{Материалы и методы исследования}

Настоящее исследование выполнено в полном соответствии с этическими нормами, обозначенными Европейской конвенцией по защите позвоночных животных, которые используются для экспериментальных и других научных целей (принята в Страсбурге 18.03.1986 и подтвержденной в Страсбурге 15.06.2006).

В исследование взяты 96 здоровых беспородных крыс-самцов, в т.ч. 34 животных в возрасте 18 мес., 30 голов, находящихся в возрасте 24 мес. и 32 головы в возрасте 30 мес. До включения в исследование все крысы были здоровы и не участвовали в исследованиях. Группа контроля состояла из 31 здоровой беспородной крысы-самца в шестимесячном возрасте. Крысы были получены в двухмесячном возрасте из питомника лабораторных животных Филиала института биоорганической химии Российской академии наук (Московская область, г. Пущино). Крысы находились в условиях вивария в достаточно больших клетках (величина площади клетки

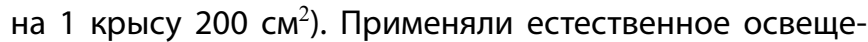
ние, температуру поддерживали 18-22 ${ }^{\circ} \mathrm{C}$, сохраняли относительную влажность на уровне 50-65\%. Все животные находились на полнорационном рационе из комбикорма для лабораторных животных марки ПК-120 (производства фирмы ООО «Лабораторкорм, г. Москва). Крысы имели свободный доступ к воде.

Все крысы взвешивались на электронных весах марки ВМ1502M-II (производство ОКБ Веста, Россия). У них оценивали их выносливость в плавательном тесте с применением груза величиной $10 \%$ от массы тела каждой крысы, который фиксировали к основанию хвоста. Тестирование животных проводили в аквариуме, имеющем глубину воды 0,8-0,9м и температуру воды 24-26C. Регистрировали время плавания до наступления признаков полной усталости, которая проявлялась в виде прекращения плавательных движений и погружением крысы под воду в течение 10 секунд [10, с. 72].

В выполненном исследовании кровь у крыс брали из вены хвоста. У всех крыс определяли уровень перекисного окисления липидов в плазме путем оценки содержания тиобарбитуровой кислоты (ТБК)-активных продуктов, применив набор производства „Агат-Мед”, количества ацилгидроперекисей с регистрацией значения плазменной антиокислительной активности [11, с. 56]. Оценивали эритроцитарный уровень перекисного окисления липидов по количеству в них малонового диальдегида и ацилгидроперекисей [12, с. 34] с учетом антиоксидантных возможностей каталазы и супероксиддисмутазы $[13$, с. 10].

Применяя световой фазовоконтрастный микроскоп Olympus CX-41 (Olympus, Япония), обеспечивающий увеличение в 1200 раз, эритроциты были разделены на дискоидные, измененные обратимо и измененные необратимо [14, с. 42].

Эритроцитарная агрегация оценивалась при световой микроскопии, применяя камеру Горяева, в ходе определения числа агрегатов эритроцитов, величины агрегированных и не вступивших в агрегацию эритроцитов после их отмытия и проведения ресуспендирования [14, с. 43]. Цифровые полученные величины были обработаны с помощью критерия Стьюдента, применив программу StatSoft STATISTICA for Windows 6.0.

\section{Результаты исслеАования}

У взятых в опыт крыс по мере повышения хронологического возраста выявлено нарастание внешних проявлений старения - потускнение и поредение шерсти, уменьшение их физической активности и аппетита у крыс, ослабление интереса к окружающей действительности. В ходе роста хронологического возраста у стареющих крыс найдено закономерное повышение массы тела, составившей у 30 месячных крыс $379,8 \pm 7,18$ г. При этом отмечено постепенное понижение уровня их выносливости в ходе проведения теста вынужденного плавания при отягощении грузом у 30 месячных крыс по сравнению с 18 месячными на 54,7\% и на 80,4\% по сравнению с контролем.

У стареющих крыс было найдено увеличение уровня активности процессов свободнорадикального окисления в липидах плазмы (уровень ацилгидроперекисей и тиобарбитуровая кислота-активных активных продуктов возросла на $21,6 \%$ и на 20,9\%, соответственно) при уменьшении антиоксидантной активности на 28,0\%. При сравнении со значениями контроля уровни ацилгидроперекисей и тиобарбитуровая кислота-активных продуктов крыс в возрасте 30 месяцев оказались повышены на 30,8\% и 26,1\%, соответственно, при этом антиоксидантная активность у них была ниже, чем в группе контроля на 35,8\% (табл.).

Сравнимые изменения перекисного окисления липидов у взятых в исследование крыс отмечены в эритро- 
Таблица. Характеристики обследованных крыс

\begin{tabular}{|c|c|c|c|c|}
\hline \multirow{2}{*}{$\begin{array}{l}\text { Регистрируемые } \\
\text { показатели }\end{array}$} & \multicolumn{3}{|c|}{ 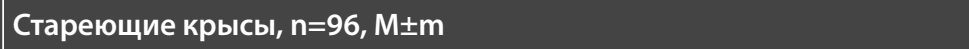 } & \multirow{2}{*}{$\begin{array}{l}\text { Контроль, } \\
\mathrm{n}=31, \mathrm{M} \pm \mathrm{m}\end{array}$} \\
\hline & 18 месячные, $n=34$ & 24 месячные, $n=30$ & 30 месячные, $n=32$ & \\
\hline Масса тела, г & $334,1 \pm 8,24^{* *}$ & $356,7 \pm 8,92^{* *}$ & $379,8 \pm 7,18^{* *}$ & $233,1 \pm 6,83$ \\
\hline Время плавания, с & $139,6 \pm 3,24^{*}$ & $114,7 \pm 4,73^{* *}$ & $90,2 \pm 6,23^{* *}$ & $162,7 \pm 4,97$ \\
\hline 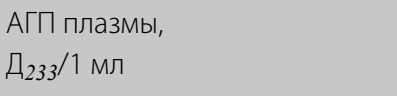 & $1,57 \pm 0,019$ & $1,84 \pm 0,028^{*}$ & $1,91 \pm 0,046^{* *}$ & $1,46 \pm 0,008$ \\
\hline ТБК-продукты, мКмоль/л & $3,63 \pm 0,019$ & $4,10 \pm 0,036^{*}$ & $4,39 \pm 0,029 * *$ & $3,48 \pm 0,012$ \\
\hline $\mathrm{AOA}, \%$ & $32,9 \pm 0,36$ & $28,4 \pm 0,28$ & $25,7 \pm 0,27^{*}$ & $34,9 \pm 0,009$ \\
\hline $\begin{array}{l}\text { АГП эритроцитов, } \\
{\text { Д } 233 / 10^{12} э р .}\end{array}$ & $2,95 \pm 0,016$ & $3,46 \pm 0,024^{*}$ & $3,98 \pm 0,015^{* *}$ & $2,84 \pm 0,017$ \\
\hline $\begin{array}{l}\text { МДА эритроцитов, } \\
\text { нмоль } / 10^{12} э р .\end{array}$ & $1,17 \pm 0,011$ & $1,42 \pm 0,008^{*}$ & $1,64 \pm 0,007^{* *}$ & $1,12 \pm 0,004$ \\
\hline $\begin{array}{l}\text { Каталаза эритроцитов, } \\
\text { ME/10 } 12 \text { эр. }\end{array}$ & $8800,0 \pm 13,2$ & $8000,0 \pm 18,5^{*}$ & $7200,0 \pm 22,8^{* *}$ & $8920,0 \pm 14,5$ \\
\hline $\begin{array}{l}\text { СОД эритроцитов, } \\
\text { МЕ/ } 10^{12} э р .\end{array}$ & $1590,0 \pm 12,70$ & $1500,0 \pm 8,16^{*}$ & $1320,0 \pm 12,27^{* *}$ & $1600,0 \pm 14,02$ \\
\hline Дискоциты,\% & $83,4 \pm 0,10$ & $76,3 \pm 0,16^{*}$ & $70,0 \pm 0,14^{* *}$ & $83,8 \pm 0,13$ \\
\hline Обратимо изм. эритроциты,\% & $9,7 \pm 0,12$ & $12,8 \pm 0,04^{*}$ & $14,9 \pm 0,10^{* *}$ & $9,6 \pm 0,08$ \\
\hline $\begin{array}{l}\text { Необратимо изм. } \\
\text { эритроциты,\% }\end{array}$ & $6,9 \pm 0,09$ & $10,9 \pm 0,16^{* *}$ & $15,1 \pm 0,12^{* *}$ & $7,1 \pm 0,14$ \\
\hline $\begin{array}{l}\text { Сумма эритроцитов, } \\
\text { вошедших в агрегаты }\end{array}$ & $32,6 \pm 0,12$ & $38,5 \pm 0,10^{*}$ & $44,7 \pm 0,16^{* *}$ & $30,3 \pm 0,08$ \\
\hline Количество агрегатов & $6,2 \pm 0,05$ & $7,0 \pm 0,12^{*}$ & $8,3 \pm 0,11^{* *}$ & $6,0 \pm 0,07$ \\
\hline $\begin{array}{l}\text { Количество свободных } \\
\text { эритроцитов }\end{array}$ & $288,5 \pm 0,25$ & $244,2 \pm 0,34^{*}$ & $225,5 \pm 0,22^{* *}$ & $294,5 \pm 0,26$ \\
\hline
\end{tabular}

Условные обозначения: достоверность различий показателей между контрольными и стареющими крысами - ${ }^{*}<0,05 ;{ }^{* *}-\mathrm{p}<0,01$

цитах - количество в них ацилгидроперекисей и малонового диальдегида увеличивались. Их количество у 30 месячных крыс превалировало по сравнению с 18 месячными на 34,9\% и 40,2\%, соответственно. Одновременно они превышали - значения контроля на 40,1\% и 46,4\%, соответственно. Активность эритроцитарных ферментов каталазы и супероксиддисмутазы у стареющих крыс в целом понижалась на 22,2\% и 20,4\%, соответственно. При этом она уступала у 30 месячных крыс уровню контроля на $23,9 \%$ и 21,2\%, соответственно (табл.).
В ходе повышения хронологического возраста в крови наблюдаемых крыс отмечено уменьшение уровня

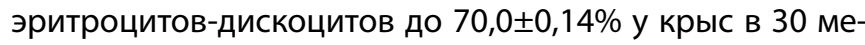
сячном возрасте, что вело к постепенному росту у них уровня измененных обратимо и необратимо эритроцитарных форм (у 30 месячных крыс по сравнению с группой контроля соответственно на 55,2\% и в 2,1 раза).

У крыс взятых в опыт крыс по мере повышения хронологического возраста отмечен рост способности к агре- 
гации эритроцитов с увеличением их общего включения в состав агрегатов и количества агрегатов при снижении уровня неагрегированных эритроцитов $(225,5 \pm 0,22)$, по сравнению с уровнем контроля (табл.).

\section{Обсужление}

Различные показатели организма, реализующие его жизнеспособность, сильно зависят от особенностей его наследственности и действия на него внешних факторов [15, с. 127]. Большое значение в этом имеет реакция на текущие условия гемостатических и реологических характеристик крови [16, с. 579], определяющих объем попадания в клетки питательных веществ и кислорода $[17$, с. 29]. Большую значимость для успеха микроциркуляции имеют особенности форменных элементов, испытывающих воздействие со стороны стенок сосудов [18, с. 43] и влияние процессов перекисного окисления липидов в организме крови [19, с. 48].

Установлено, что в ходе старения у крыс слабеет антиоксидантная активность плазмы, приводя к повышению в ней уровня ацилгидроперекисей и тиобарбитуровая кислота-активных продуктов. Избыточное перекисное окисление липидов в плазме повреждает стенки сосудов и рецепторы на мембранах клеток крови, в том числе эритроцитов, негативно влияя на их состоянии [20, с. 1485]. При этом в эритроцитах слабеет антиоксидантная защита, что усиливает в них процессы пероксидации липидов.

Избыточное перекисное окисление липидов в плазме и мембранах эритроцитов нарушает структурно-функциональные характеристики мембран и белкового цитоскелета красных кровяных телец. На фоне усиленного перекисного окисления липидов в эритроцитах возникает ослабление синтеза аденозинтрифосфата, понижая активность ионных насосов, которые в этих условиях уже не справляются с выбросом увеличивающегося притока $\mathrm{Ca}^{2+}$ и $\mathrm{Na}^{+}$и поддержанием оптимума уровня $\mathrm{K}^{+}[21$, с. $278 ; 22$, с. 963]. В ходе повышения в эритроцитах уровня $\mathrm{Ca}^{2+}$, уменьшения $\mathrm{K}^{+}$и роста уровня $\mathrm{Na}^{+}$уменьшается объем воды и растет концентрация гемоглобина, что меняет форму определенного количества красных кровяных телец. Очевидно, нарушение цитоархитектоники связано с изменениями структуры спектрина за счет активации перекисного окисления липидов и уменьшения расстояния между молекулами спектрина. В этих условиях уменьшается площадь поверхности внутренней части липидного бислоя и формируются эхиноциты. Также в этих условиях меняется фосфолипидный комплекс мембраны с появлением безбелковых зон, которые быстро объединяются. Появляются избыток $\mathrm{Ca}^{2+}$ соединяется с некоторыми полярными кислотнофосфатными группами в липидном бислое и ведет к образованию их структурных связей. В конечном итоге это ведет к уменьшению внутренней части липидной мембраны и формированию из эритроцита сфероэхиноцита [23, с. 27].

В этих условиях развивается постепенное повышение количества эритроцитов, не имеющих двояковогнутой формы. Возникающие изменения в эритроцитах обеспечивает рост содержания в крови обратимо и необратимо измененных их разновидностей. Так, у животных в возрасте 30 месяцев существенно растет уровень эритроцитов, претерпели явления эхиноцитоза в сферы с наличием на их поверхности шипов вариабельной формы и путем стомацитоза до состояния диска односторонне выгнутого. Дальнейшая трансформация таких эритроцитов быстро ведет к появлению сфероэхиноцита, сферостоматоцита и обязательно сфероцита, способного в короткие сроки лизироваться. Данные изменения тормозят ход гемоциркуляции по сосудам и, в первую очередь, по капиллярам. Затруднения микроциркуляции вызваны с тем, что в ходе сквозь капилляры все эритроциты должны испытывать удлинение и обретать эллипсоидную форму. Данная способность наибольшая у дискоцитов. Только они способны удлиняться от 8 до 17 мкм. Вместе с тем, сфероэхиноцит может удлиняться только от 5,5 до 8 мкм, а эритроцит-сферостоматоцит удлиняется от 5,5 до 7 мкм [24, с. 793]. В крови эритроциты-сфероциты постоянно испытывают вращение и проявляют себя как весьма жесткие частицы. В этой связи их реологические свойства наихудшие, чем у всех остальных эритроцитах $[25$, с. 30].

Найденное у крыс в ходе старения повышение активности агрегации эритроцитов сильно обеспечивается возникающими изменениями в уровне заряда на их мембранах по причине деградации на них некоторого количества гликопротеинов под действием избытка перекисного окисления липидов. Усиление синтеза активных форм кислорода создает у стареющих крыс условия для оксидативной альтерации мембран и повреждение плазменных протеинов плазмы, имеющих способность сцеплять как «мостики» эритроциты в ходе их агрегации. Усиливающееся перекисное окисление липидов в плазме и в эритроцитах наращивает порог процесса их дезагрегации за счет усиления соединения красных кровяных телец в агрегаты, увеличения скорости этого процесса вследствие оксидативных повреждений их мембран [5, с. 364].

Видимо, найденное в ходе старения у крыс усиление выраженности агрегации эритроцитов значимо обеспечено усилением влияния катехоламинов, содержание которых в случае любых неблагополучий в организме и на фоне старения увеличивается. В условиях актива- 
ции $\mathrm{a}_{l}$-рецепторов главными месенджерами являются система $\mathrm{Ca}^{2+}$-кальмодулина и «цепь» превращений фосфатидилинозитола. Рост уровня активности $\mathrm{a}_{2}$-адренорецепторов ведет к ослаблению аденилатциклазы на фоне влияний с рецепторов на $\mathrm{Gi}$ - белки, понижая уровень циклического аденозинмонофосфата в клетке, вызывающего вход в нее $\mathrm{Ca}^{2+}$ и усиливающего агрегацию эритроцитов [8, с. 30].

Рост с возрастом числа в крови крыс свободных агрегатов обеспечивало повреждение сосудистого эндотелия, что способствовало контакту субэндотелия и крови и активации процессов гемостаза, что значимо ухудшало микрореологию крови в капиллярах [10, с. 73]. Повышение уровня свободно перемещающихся по сосудам агрегатов может блокировать некоторое количество vasa vasorum, что ведет к дистрофии в стенках сосудов и ослабляет в сосудах синтез веществ, обеспечивающих гемостатический контроль и контроль над агрегацией эритроцитов [13, с. $11 ; 20$, с. 1500].

\section{Зак^ючение}

У крыс в ходе старения найдено постепенное уменьшение уровня антиоксидантной активности плазмы. Это сопровождается ростом в ней уровня продуктов перекисного окисления липидов. Складывающаяся ситуация вызывает альтерацию наружных мембран - эритроцитов, что отрицательно сказывается на их функциях. В ходе старения у крыс прогрессивно растет агрегационная готовность и степень изменения поверхностных свойств эритроцитов. Это имеет большое значение для увеличения по мере старения морбидной отягощенности и ослабления всего организма в отношении воздействия негативных влияний внешней среды.

\section{ЛИТЕРАТУРА}

1. иишкун, А. А. Биологический возраст и старение: возможности определения и пути коррекции / А. А. Кишкун.— М.: ГЭОТАР-Медиа, 2008. — $976 c$.

2. Амелина, И. В. Проявление транскрипционной активности ядрышкообразующих районов хромосом в Курском регионе / И. В. Амелина, И. Н. Медведев // Бюллетень экспериментальной биологии и медицины. - 2009. -Т. 147, № 6. - С. 671-673.

3. Жукова, О. Б. Влияние экспериментального десинхроноза на липидный обмен у крыс при ожирении / О. Б. Жукова, К. В. Зайцев, Н. П. Степанко, А. А. Гостюхина, С. С. Гутор, И. И. Вебер, Д. А. Нимирская, С. А. Межерицкий, Н. Г. Абдулкина // Вестник Томского государственного университета. Биология.2013. - № 4(24). - С. 145-151.

4. Скорятина И. А. Современные взгляды на терапию дислипидемии, сочетающейся с артериальной гипертонией // Ульяновский медико-биологический журнал.— 2016.—№ 2.-С. 8-19.

5. Донцов, В. И. Медицина антистарения: фундаментальные основы / Предисловие В. Е. Шабалина / В. И. Донцов, В. Н. Крутько, А. И. Труханов.-М.: КРАСАНД, 2010.-680с.

6. Громнацкий, Н. И. Коррекция нарушений тромбоцитарного гемостаза немедикаментозными средствами у больных артериальной гипертонией с метаболическим синдромом / Н. И. Громнацкий, И. Н. Медведев // Клиническая медицина.— 2003.—Т.81, № 4.—C. 31-34.

7. Ferroni, P. Platelet function in health and disease: from molecular mechanisms, redox considerations to novel therapeutic opportunities / P. Ferroni, N. Vazzana, S. Riondino, C. Cuccurullo, F. Guadagni, G. Davm // Antioxid Redox Signal.—2012.—Vol.17(10).—P.1447-1485. doi: 10.1089/ars.2011.4324.

8. Морозова, В. Т. Эритроциты: структура, функции, клинико-диагностическое значение / В. Т. Морозова, С. А. Луговская, М. Е. Почтарь // Клиническая лабораторная диагностика.—2007.- № 10.- С. 21-35.

9. Завалишина, С. Ю. Микрореологические особенности эритроцитов у регулярно тренирующихся кандидатов и мастеров спорта по легкой атлетике первого зрелого возраста / С. Ю. Завалишина, Т. С. Мальцева // Вестник новых медицинских технологий. — 2012. — Т.XIX, № 2. — С. $134-135$.

10. Каркищенко, В.Н. Разработка методики оценки физической выносливости мелких лабораторных животных для изучения адаптивной активности некоторых лекарственных препаратов / В. Н. Каркищенко, Г.Д. Капанадзе, С. Е. Деньгина, Н. В. Станкова // Биомедицина.— 2011.- № 1.C. $72-74$.

11. Волчегорский, И. А. Экспериментальное моделирование и лабораторная оценка адаптивных реакций организма / И. А. Волчегорский, И. И. Долгушин, 0.Л. Колесников, В. Э. Цейликман.—Челябинск. 2000. - 167 с.

12. Гаврилов, В. Б. Спектрофотометрическое определение содержания гидроперекисей липидов в плазме крови / В. Б. Гаврилов, М. И. Мишкорудная // Лабораторное дел0.-1983.— № 3.-С.33-36.

13. Чевари, С. Определение антиоксидантных параметров крови и их диагностическое значение в пожилом возрасте /С. Чевари, Т. Андял, Я. Штренгер // Лабораторное дело.—1991.— № 10.—C. 9-13.

14. Медведев, И. Н. Методические подходы к исследованию реологических свойств крови при различных состояниях /И.Н. Медведев, А. П. Савченко, С. Ю. Завалишина, Е. Г. Краснова, Т. А. Кумова, О. В. Гамолина, И. А. Скорякина, Т. С. Фадеева // Российский кардиологический журнал.—2009.—№ 5.—C. $42-45$.

15. Кутафина, Н. В. Оценка тромбоцитарной активности в модели создания дислипидемии у крыс разного возраста / Н. В. Кутафина, С. Ю. Завалишина //Ульяновский медико-биологический журнал. - 2016. — № 3.— С. 126-133.

16. Медведев, И. Н. Активность тромбоцитарного гемостаза у детей с искривлениями позвоночника / И. Н. Медведев, Е. В. Лапшина, С. Ю. Завалишина // Бюллетень экспериментальной биологии и медицины.—2010.— - 
17. Симоненко, В.Б. Активность первичного гемостаза у больных артериальной гипертонией с нарушением толерантности к глюкозе на фоне трандолаприла / В. Б. Симоненко, И. Н. Медведев, О. В. Гамолина // Клиническая медицина.—2011.— № 2.—C. 29-31.

18. Медведев, И. Н. Динамика нарушений внутрисосудистой активности тромбоцитов у крыс в ходе формирования метаболического синдрома с помощью фруктозной модели /И.Н. Медведев // Вопросы питания.—2016.—Т. 85, № 1.—C. 42-46.

19. Медведев, И. Н. Выраженность тромбоцитарной активности у больных артериальной гипертонией 3-й степени при метаболическом синдроме / И. Н. Медведев, С. Ю. Завалишина // Кардиология.—-2016.— Т. 56, № 1.—C. 48.

20. Dale, J. Marino. Age-Specific Absolute and Relative Organ Weight Distributions for Fischer 344 Rats / Dale J. Marino. // Journal of Toxicology and Environmental Health, Part A: Current Issues.—2012.—Vol.75(24).—P.1484-1516. doi: 10.1080/15287394.2012.722520.

21. Epel, E. S. Cell aging in relation to stress arousal and cardiovascular disease risk factors / E. S. Epel, J. Lin, F. H. Wilhelm et al. // Psychoneuroendocrinology. - 2006.Vol. 31, № 3.-P. 277-287.

22. Seehuus, S. C. Reproductive protein protects functionally sterile honey bee workers from oxidative stress / S. C. Seehuus, K. Norberg, U. Gimsa et al. // Proc. nat. Acad. Sci. USA.—2006.—Vol.103, № 4.-P. 962-967.

23. Шабанов, В. А. Общие и клинические вопросы гемореологии /В.А. Шабанов. — Н. Новгород: изд-во Ниж.ГМА, 1998. - 32 с.

24. Pasini, E. M. In-depth analysis of the membrane and cetosolic proteome of red blood cells / E. M. Pasini, M. Kirkegaard, P. Mortensen // Blood.—2006.—V.108, № 3. - P. 791-801.

25. Завалишина, С. Ю. Динамика микрореологических особенностей эритроцитов у детей 7-8 лет со сколиозом на фоне лечебной физической культуры и массажа / С. Ю. Завалишина, Е. В. Нагибина // Технологии живых систем._-2012.—T.9, № 4.—C. 29-33.

(c) Гришан Маргарита Алексеевна ( grishanma@rgsu.net ), Котова Татьяна Владимировна ( kotova-nm@mail.ru ).

Журнал «Современная наука: актуальные проблемы теории и практики»

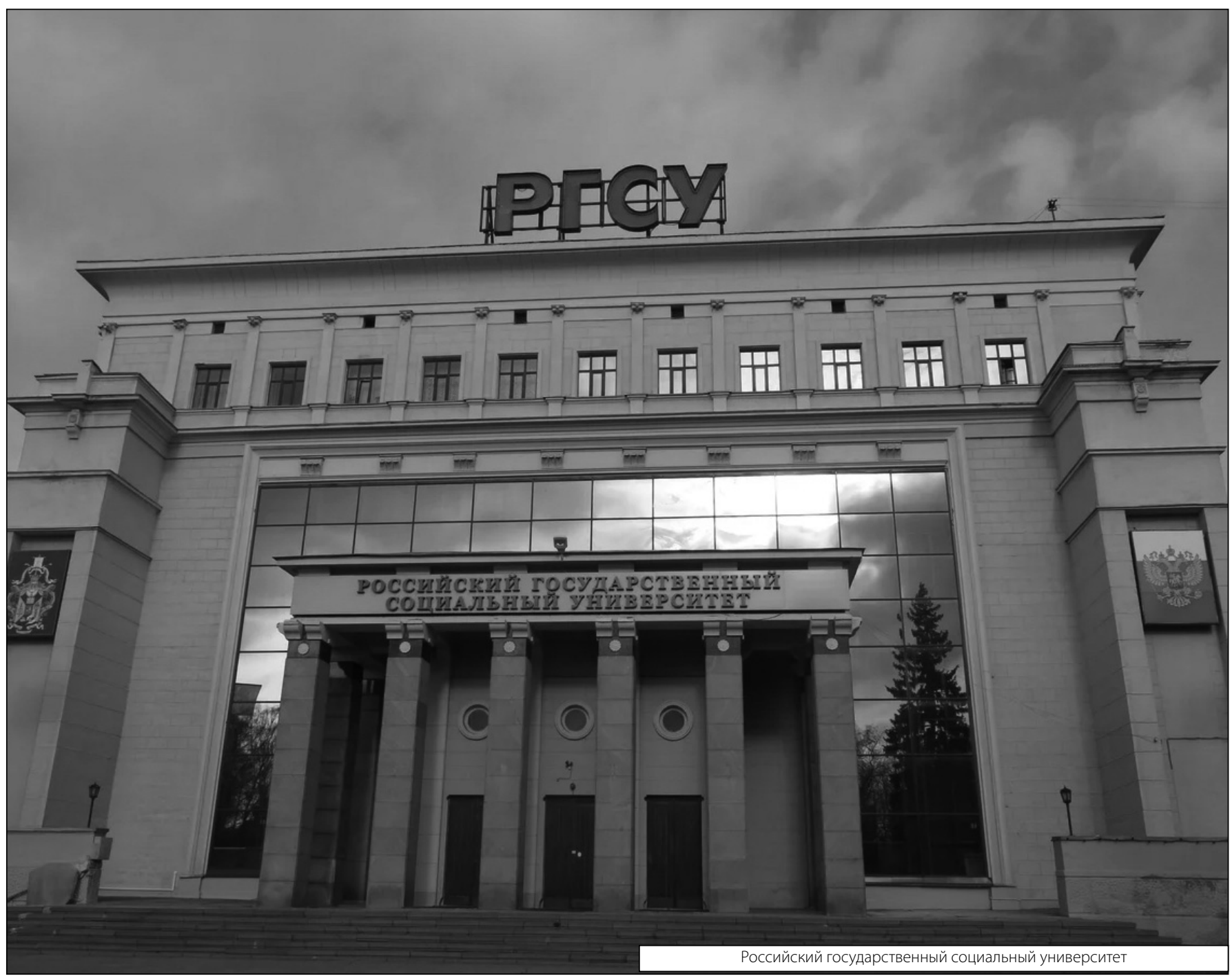

